\title{
Continuing Education-XIX Continuing Education Investments for Staff Development Benefits
}

While much has been done to resolve the issue, one can still hear an occasional debate over the distinction between continuing education and staff development. It s important to know there is a difference and to understand what this difference means, but it is somewhat bothersome that more attention is given to the difference than to the potential mutual benefits.

Most people would agree that continuing education is the general term with a more specific focus. Learning activities in this category are designed specifically with the individual learner in mind-no matter what library he or she works in. Staff development, on the other hand, is designed with organizational needs in mind, and while the individual does benefit, the basic purpose is to help him or her do a better job. Continuing education and staff development merge at the point where the individual and the organization benefit equally. This is where a focus on mutual benefits can strengthen the general learning climate for all library personnel.

Since libraries are not typically overburdened with resources to launch full-blown staff development programs with their own trainers and training coordinators, careful planning is a must to make the most of educational investments. At the same time, continuing education programers are constantly seeking dependable needs assessment and an ongoing market for their activities. A productive mutual interest can be found in this condition, and it really hasn't yet been plumbed for all of its potential

If management has a sound planning and communication program in place, supervisory levels should be able to identify educational needs in their departments that can be met externally through continuing education activities planned for the individual learner. To prime the library for an effective use of these external learning opportunities, supervisors should work with staff to identify the training needs that cannot be met internally with current staff development programs. They can also locate a variety of alternatives that will meet their training objectives, determine with all key personnel what the department should get out of the external training investment, plan for dispersing the work load of the individual while he or she is at the learning activity, anticipate integrating the new skills after the learner has returned to the department, and set up a mechanism for sharing the learning with appropriate colleagues as a follow-up to the learning experience.

With this kind of planning, any library can maximize the organizational utility of sending staff to continuing education activities that have been designed primarily for the benefit of individual learners. For the continuing education developers, a management system that generates these prepared learners will also generate defined training needs that may well be the basis of many other learning activities for their consumers.

Sound planning of this type can also strengthen the management function of training, which is a central focus in any human resource development program. Considering that we spend from 60 percent to 90 percent of our budgets on human resources in this labor-intensive profession; the opportunity to maximize continuing education investments for staff development benefits should become more an issue than pointing out differences.-Jim Nelson.

Editor's Note: Jim Nelson is assistant professor of library science in the University of WisconsinExtension Communication Programs and in the University of Wisconsin-Madison School of Library Science.

\section{Subscription Service Tailored To Your Needs}

Librarians throughout the world use Faxon's computerized technology to manage their serials acquisitions. Utilizing the most advanced subscription processing system, Faxon combines personal attention with a completely automated range of subscription services tailored to your library's particular needs. Faxon offers over 95,000 titles, flexible ordering and renewal plans, a yearly invoice with full periodical information, and Faxon's Automated Claim System (FACS), plus many other valuable subscription services.

Write or call Faxon today for our LIBRARIANS' GUIDE and SERVICE BROCHURE.

Library business is our only business - since 1881.

\section{ENEF. F.W. FAXON COmPAnY, InC.}

Library Magazine Subscription Agency

15 Southwest Park, Westwood, Mass. 02090 Tel: $800 \cdot 225 \cdot 6055$ (toll free)

$617-329-3350$ (collect in Mass. and Canada only) 


\section{VALUABLE BOOKS FOR THE LIBRARY}

ALCHEMY. The Medieval Alchemists and their Royal Art

by Johannes Fabricius. The mystery and magic of medieval alchemy recaptured in a giant book containing more than 400 stunning woodcuts, engravings, water-colours and paintings. "Next to the works of Jung himself, this appears to be the most explicit that has been written on alchemy ..." - Ambix, vol, 24, no. 3 . In English. 1976. Bound. Large folio. D.Kr. 250.-

\section{THE DAMASCuS PENTATEUCH. Part 1}

Ms. Jewish National and University Library, Jerusalem (former the Sassoon Library). With an introduction in English by D.S. Loewinger. (Early Hebrew Manuscripts in Facsimile, vol. h). 1978. Large folio. Subscription price, paper bound D.Kr. 2,240.-, bound in cloth D.Kr. 2,400.--. Single volumes at non-subscription rates are 25 per cent higher. Please write for detailed prospectus.

\section{A BIBLIOGRAPHY OF DANISH CONTRIBUTIONS TO CLASSICAL SCHOLARSHIP}

From the sixteenth Century to 1970. By Peter Allan Hansen. Including a large number of little known items, both old and recent, in Latin, English, French and German. Edt. by the Royal Library, Copenhagen. In English. 1977. Bound. D.Kr. 190.-.

\section{KNOWLEDGE AND POWER}

The Role of Stalin's Secret Chancellery in the Soviet System of Government. By N.E. Rosenfeldt. Edt. by the Institute of Slavonic Studies, Copenhagen University. In English. 1978. D.Kr. 80.-

\section{THE WITCH ON THE WALL}

Medieval Erotic Sculpture in the British Isles. Thesis by Jörgen Andersen. Profusely illustrated. In English. 1977. Bound. D.Kr. 120.-

\section{HANS CHRISTIAN ANDERSEN AS AN ARTIST}

by Kjeld Heltoft. Profusely illustrated. "Don't you find Andersen's fairy tales very fine? It's certain that Andersen also draws illustrations". - Vincent wan Gowh. In English. 1977. Bound. D.Kr. 100.-

\section{BIBLIOTHECA DANICA}

The Danish national bibliography within the period 1482-1830. Reprint 1961-63 with new additions and references. A complete catalogue of books issued in Denmark. Norway (until 1814), Holstein and Iceland. 5 volumes in quarto. Strongly bound. D.Kr. 1,100.-

\section{BIBLIOTHECA NORVEGICA}

by Hjalmar Pettersen. Norway's national bibliography till First World War. Reprint of the original edition 1899-1924. 4 vols. in quarto. Bound. D.Kr. 1,480,-

\section{BRUNET: MANUEL DU LIBRAIRE ET DE L'AMATEUR DE LIVRES}

with supplementary volumes and DESCHAMPS: Dictionnaire de Géographie Ancienne et Moderne. Reprint 1966-68. 9 vols. Bound. D.Kr. 1,100,-.

\section{DANSK BOGFORTEGNELSE}

Danish Book-Index 1841-80 in reprint 1960-63. Recording alł books printed in Denmark and Iceland during the years of 1841-1880. 3 vols. D.Kr. $585,-$

\section{DANSK HISTORISK BIBLIOGRAFI}

Danish Historical Bibliography $1913-42$ by Dr. Phil. Henry Bruun. 6 vols. Bound D.Kr. 315,-

FINNUR JONSSON: DEN NORSK-ISLANDSKE SKJALDEDIGTNING

The most important work to illustrate the early Scandinavian literature. Part A: 2 vols. bound (reprint 1967) D.Kr. 400,- Part B: 2 vols. bound (reprint 1974) D.Kr. 600,-

\section{OLAUS MAGNUS: HISTORIA DE GENTIBUS SEPTENTRIONALIBUS, Rome 1555}

Reprint of Olaus Magnus' superb cultural history. With an introduction in English by John Granlund, Stockholm. Bound. D.Kr. 740,-

\section{NOUVELLE BIOGRAPHIE GENÉRALE}

The most comprehensive international biographical encyclopedia in the world with 52.420 biographies. Reprint 1963-69. 46 volumes, strongly bound in 23 double volumes. D.Kr. 4.200,-

\section{WARMHOLTZ: BIBLIOTHECA HISTORICA SVEO-GOTHICA}

The national bibliography of Sweden up to 1780 with an index from 1899. Reprint 1966-68. 15 vols. + Index in 8 double vols. Bound. D.Kr. 950,-

\section{BIBLIOGRAPHIA GROENLANDICA}

by $P$. Lauridsen. Only existing Greenland bibliography and the principal source to the early Greeniand literature and literature on Greenland till the year 1880 . Complete register on works, treatises and maps from all over the world together with Danish manuscripts, total 2,857 annotated entries. Reprint 1979. Bound. D.Kr. 150.-

\section{DICTIONARY OF THE RUSSIAN ACADEMY}

Vols. 1-6, 1806-1822 plus suppl. volume. Containing some 50,000 words from contemporary and older Russian texts. An indispensable supplement to other dictionaries when studying Russian literature from the 18 th and 19 th centuries. Reprint 1972. Bound. D. Kr. 3,000.-

\section{HISTORY OF THE RUSSIAN HIERARCHY (ISTORIJA ROSSIJSKOJ IERARCHII)}

Volumes 1 and 2 with the Catalogue of Monasteries from Volume 3 . Collected by A.A. Ornatskij. A modern reprint edition of the famous - and extremely rare - work on the history of the Russian Orthodox Church. Re-edited with an Introduction in English by Mads Oesterby, In Russian. Bound. D.Kr. 1,185.—.

ROSENKILDE AND BAGGER International Booksellers and Publishers 